\title{
PENGARUH PENGGUNAAN LABORATOIUM VIRTUAL DALAM PEMBELAJARAN INKUIRI TERBIMBING TERHADAP PENGUASAAN KONSEP KALOR PESERTA DIDIK
}

\author{
Hermansyah, Gunawan, Ahmad Harjono \\ Program Studi Magister Pendidikan IPA \\ Program Pascasarjana, Universitas Mataram \\ Jalan Majapahit No. 62, Mataram \\ E-mail: hermannsyahfisika@unram.ac.id
}

\begin{abstract}
The purpose of this study is to examine the effect of using virtual laboratory in guided inquiry learning on students' mastery concept of heat material. This study is quasi experiments with posttest only control group design. There were 58 respondents in this study which were divided into two group; experimental group and control group. The data were analyzed by using t-test. The results showed that experimental groups' mastery concepts significantly differed from the control group. It can be concluded that the use of virtual laboratory in guided inquiry learning model affects students' mastery concepts of heat material.
\end{abstract}

Keywords: guided inquiry learning, heat, mastery concept, virtual laboratory

\section{PENDAHULUAN}

Salah satu permasalahan yang dihadapi pendidik dalam pembelajaran fisika khususnya pada materi kalor adalah penguasaan konsep peserta didik pada materi ini masih terbilang rendah. Penguasaan konsep yang baik dapat membantu peserta didik dalam mengklasifikasikan dan menganalisis masalahmasalah, sehingga mereka dapat mengatasi kesulitan-kesulitan dalam mempelajari materi kalor dan dapat belajar dengan lebih bermakna daripada sekedar menghafal secara berulangulang tanpa makna.

Penguasaan konsep peserta didik pada materi kalor dapat diperoleh apabila kegiatan pembelajaran mengarahkan peserta didik untuk mendapatkan pengalaman-pengalaman ilmiah. Berdasarkan hasil observasi menunjukkan bahwa pembelajaran yang disampaikan oleh guru berbanding terbalik dengan cara-cara untuk memperoleh pengalaman-pengalaman ilmiah tersebut. Kegiatan pembelajaran yang diterapkan oleh guru dalam pembelajaran hanya sekedar mengajak peserta didik untuk memverifikasi fakta dari konsep yang telah disampaikan. Kegiatan seperti hal tersebut jelas belum mendukung secara optimal kegiatan untuk memperoleh pengalaman ilmiah peserta didik. Hal ini menyebabkan peserta didik merasa kesulitan dalam memahami konsepkonsep pada materi kalor dan bahkan peserta didik tidak mampu untuk membentuk konsepsi yang benar serta tidak mampu untuk mengkonstruk pengetahuannya, sehingga berdampak terhadap rendahnya penguasaan konsep peserta didik.

Pengajaran pada materi kalor akan lebih efektif apabila dalam pembelajaran diterapkan kegiatan-kegiatan yang mampu mengkonstruk pengetahuan peserta didik lewat pengalamanpengalaman ilmiah. Kegiatan laboratorium dalam pembelajaran inkuiri terbimbing merupakan salah satu kegiatan pembelajaran yang dapat mendukung hal tersebut secara optimal. Hasil riset PSSC (Physical Science Study Committe) di amerika serikat tahun 1956, menunjukkan bahwa menggunakan kegiatan laboratorium dengan inkuiri sebagai pendekatan utama dalam belajar fisika, terbukti berhasil membangkitkan minat dan 
kemampuan peserta didik (Wahyana, 2001). Peserta didik dapat menemukan hukum, mampu menghitung, mengukur, mengamati dan berinkuiri sesuai dengan pola pikirnya, seperti layaknya yang dilakukan oleh seorang peneliti (Wahyana, 2001).

Kegiatan laboratorium dalam pembelajaran inkuiri dirasa sangat penting untuk menunjang pemahaman peserta didik terhadap konsep kalor. Pullaila (2007) menyatakan bahwa kegiatan laboratorium memiliki keuntungan psikologis seperti memperkaya pengalaman dengan hal-hal yang bersifat objektif, realistis, dan menghilangkan verbalisme, serta manfaat dari kegiatan laboratorium adalah menambah minat dan aktivitas belajar peserta didik serta memberikan pemahaman yang lebih tepat dan jelas. Tetapi dalam pelaksanaannya, kegiatan laboratorium tidak sepenuhnya dapat terlaksana. Hal ini disebabkan oleh keterbatasan alat dan bahan laboratorim yang menunjang kegiatan laboratorium secara sempurna. Selain itu, Hermansyah et al. (2015) mengemukakan bahwa kegiatan laboratorium tidak dapat terlaksana sepenuhnya karena pembelajaran melalui kegiatan laboratorium memerlukan alat praktikum yang cukup mahal, pemanfaatan alat praktikum yang masih belum efektif dan secara teknik memerlukan waktu yang lebih lama dalam kegiatan eksperimen, serta dalam penyampaian konsep-konsep fisika yang bersifat abstrak di dalam kelompok sangat sulit divisualisasikan atau ditampilkan prosesnya secara langsung sekalipun melalui kegiatan laboratorium.

Seiring dengan adanya masalah keterbatasan alat praktikum dan permasalahanpermasahalan lain seperti yang disebutkan di atas, maka dibutuhkan suatu inovasi yang mampu mengatasinya. Salah satu inovasinya yaitu pemanfaatan laboratorium virtual dengan berbasis komputer sebagai media dalam kegiatan laboratorium. Penggunaan laboratorium virtual berbasis komputer melibatkan keaktifan peserta didik sebagai pengguna dalam aktivitas-aktivitas inkuiri yang mengutamakan pengalaman ilmiah di dalam proses pembelajaran. Gunawan \& Liliasari (2012) mengemukakan sejumlah bentuk interaksi yang dapat dimunculkan melalui media komputer seperti penyajian praktik dan latihan, tutorial, permainan, simulasi, penemuan, dan pemecahan masalah. Pemanfaatan labooratorium virtual untuk mendukung keterlaksanaan kegiatan praktikum diharapkan dapat memenuhi ketercapaian dari tujuan pembelajaran fisika.

Beberapa penelitian yang mendukung tentang pengaruh dari penggunaan laboratorium virtual terhadap penguasaan konsep peserta didik. Junaidi et al. (2016) menyatakan bahwa penggunaan model pembelajaran virtual laboratory berbasis inkuiri berpengaruh terhadap penguasaan konsep gelombang peserta didik. Sejalan dengan itu, Hermansyah et al. (2015) menyatakan bahwa penggunaan laboratroium virtual berpengaruh terhadap penguasaan konsep dan keterampilan berpikir kreatif peserta didik. Hayati et al. (2017) menyatakan bahwa penggunaan media simulasi dalam pembelajaran inkuiri berpengaruh terhadap hasil belajar fisika peserta didik. Kusdiastuti et al. (2016) menyatakan bahwa model pembelajaran inkuri berbantuan laboratorium virtual berpengaruh terhadap penguasaan konsep fisika peserta didik.

\section{METODE PENELITIAN}

Penelitian ini termasuk penelitian kuasi eksperimen yang bertujuan untuk mengetahui pengaruh perlakuan terhadap variabel terikat dalam kondisi yang dikendalikan (Creswell, 2012). Penelitian dilakukan di SMAN 4 Mataram tahun ajaran 2017/2018. Populasi penelitian adalah seluruh peserta didik kelompok XI IPA SMAN 4 Mataram berjumlah 
148 peserta didik. Sampel sebanyak 2 kelompok yakni kelompok XI IPA 3 berjumlah 29 peserta didik sebagai kelompok kontrol dan kelompok XI IPA 4 berjumlah 29 peserta didik sebagai kelompok eksperimen yang diambil menggunakan teknik cluster random sampling. Penelitian ini menggunakan posttest only control group design. Data penguasaan konsep, diperoleh sesudah diberikan perlakuan yang berguna untuk mengetahui tingkat penguasaan konsep peserta didik.

Pengumpulan data penguasaan konsep peserta didik menggunakan instrumen yang berbentuk pilihan ganda sebanyak 26 butir soal dengan lima alternatif pilihan jawaban dan 6 soal berbentuk esay. Penguasaan konsep yang dimaksud adalah hasil belajar peserta didik ranah kognitif C1 sampai C6 pada materi kalor dengan sub materi pemuaian, kalor, perubahan wujud zat, azas Black, dan perpindahan kalor. Data yang diperoleh terlebih dahulu diuji normalitas distribusi dan homogenitas varian sebagau uji prayarat sebelum dianalisis menggunakan uji-t untuk mengetahui pengaruh penggunaan laboratorium virtual dalam pembelajaran inkuiri tervimbing terhadap penguasan konsep kalor peserta didik.

\section{HASIL DAN PEMBAHASAN}

Terdapat dua kegiatan yang dilakukan pada penelitian ini yaitu pembuatan program laboratorium virtual sebagai media pembelajaran dan pengimplementasiannya dalam proses pembelajaran berbasis inkuiri terbimbing. Pembuatan program dilakukan dalam empat tahap, yaitu: 1) analisis pendahuluan tentang kebutuhan akan laboratorium virtual dan analisis materi berdasarkan kompetensi dasar, dan indikator; 2) mendesain flow chart dan story board; 3) melakukan pengembangan berdasarkan analisis dan desain yang telah ditentukan menggunakan adobe flash prosesional CS 5 sehingga dihasilkan laboratorium virtual yang teridiri dari kompetensi, materi, dan enam simulasi yang telah dikembangkan oleh peneliti sebelumnya; dan 4) uji kelayakan yang dilakukan oleh ahli guna mengetahui kelayakan laboratorium virtual yang dihasilkan sebelum diimplementasikan dalam proses pembelajaran. Berdasarkan uji kelayakan oleh ahli, laboratorium virtual dinyatakan layak untuk diimplementasikan dalam proses pembelajaran. Pada tahap implementasi, peserta didik diberikan perlakuan dengan penggunaan laboratorium virtual dalam pembelajaran inkuiri terbimbing pada kelompok eksperimen dan konvensional pada kelompok kontrol.

Tes akhir diberikan setelah peserta didik mendapatkan perlakuan dengan 26 butir soal dalam bentuk pilihan ganda dan 6 soal dalam bentuk esay yang mencakup lima sub materi. Berdasarkan tes akhir yang dilakukan maka diperolehan nilai rata-rata penguasaan konsep kelompok eksperimen dan kelompok kontrol seperti disajikan pada Tabel 1.

Tabel 1. Nilai Rata-Rata Penguasaan Konsep Peserta Didik

\begin{tabular}{lcc}
\hline Kelompok & $\begin{array}{c}\text { Jumlah } \\
\text { Peserta Didik }\end{array}$ & $\begin{array}{c}\text { Nilai } \\
\text { Rata-Rata }\end{array}$ \\
\hline Eksperimen & 29 & 62,20 \\
Kontrol & 29 & 50,57 \\
\hline
\end{tabular}

Berdasarkan perolehan nilai rata-rata pada Tabel 1, diketahui bahwa nilai rata-rata kelompok eksperimen sebesar 62,20 dan nilai rata-rata kelompok kontrol sebesar 50,57. Hal ini menunjukkan bahwa perolehan nilai ratarata penguasaan konsep kelompok eksperimen jauh lebih tinggi dibanding kelompok kontrol. Perbandingan pencapaian penguasaan konsep antara kelompok eksperimen dan kelompok kontrol ditampilkan pada Gambar 1. 


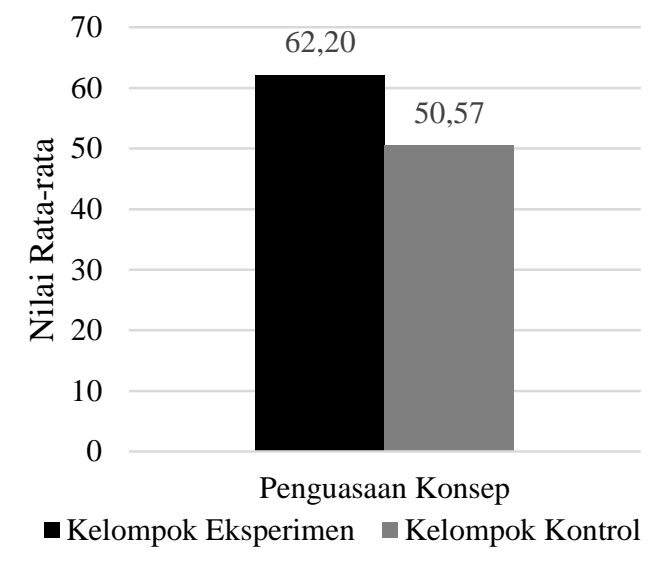

Gambar 1. Perbandingan Nilai Rata-Rata Penguasaan Konsep Kedua Kelompok

Selanjutnya hasil tes akhir digunakan untuk perhitungan uji normalitas dan uji homogenitas sehingga diperoleh bahwa data penguasaan konsep kedua kelompok berdistribusi normal dan varian kedua kelompok adalah homogen. Setelah uji prasyarat dilakukan, kemudian dilakuakn uji statistik menggunakan uji-t dengan taraf signifikan $5 \% \quad(0,05)$ untuk mengetahui perbedaan kedua kelompok dan mengetahui pengaruh perlakuan yang diberikan. Berdasarkan hasil uji-t diperoleh nilai $t_{\text {hitung }}$ sebesar 4,865 dengan taraf signifikansi 0,000. Karena taraf signifikansi $0,000<0,05$ maka kelompok eksperimen berbeda secara siginifikan dengan kelompok kontrol pada penguasaan konsep kalor, dimana penguasaan konsep kelompok eksperimen lebih baik dibandingkan dengan kelompok kontrol. Karena terdapat perbedaan yang signifikan antara kelompok eksperimen dengan kelompok kontrol, maka disimpulkan bahwa penggunaan laboratorium virtual dalam pembelajaran inkuiri terbimbing berpengaruh terhadap penguasaan konsep peserta didik pada materi kalor. Hasil penelitian ini sejalan dengan Nugroho et al. (2013) yang menyatakan bahwa pembelajaran IPA dengan metode inkuiri terbimbing menggunakan laboratorium virtual lebih baik dibandingkan dengan pembelajaran IPA dengan metode inkuiri menggunakan laboratorium riil. Muthmainnah et al. (2017) menyatakan bahwa metode pembelajaran fisika berbasis eksperimen virtual berpengaruh terhadap hasil belajar fisika peserta didik. Demikian juga dengan Bortnik et al. (2017) yang menyatakan bahwa penggunaan pendekatan yang memadukan prakti dan virtual berpengaruh terhadap keterampilan dan kemampuan praktik peserta didik pada pembelajaran kimia analitik. Pada penggunaan laboratorium virtual dalam model pembelajaran generatif, Sugiana et al. (2016) juga menyatakan bahwa penggunaan laboratorium virtual berpengaruh terhadap penguasaan konsep fisika peserta didik.

Perbedaan pencapaian penguasaan konsep kedua kelompok disebabkan karena pada kelompok eksperimen menggunakan laboratorium virtual dalam pembelajaran inkuiri yang mampu memberikan kesempatan pada peserta didik untuk lebih leluasa dalam melakukan praktikum secara mandiri tanpa rasa takut akan terjadi kerusakan saat melakukan kegiatan eksperimen dan memungkinkan peserta didik untuk menemukan suatu konsep melalui pengalaman-pengalaman ilmiah sehingga pembelajaran yang dilakukan menjadi lebih bermakna.

Penemuan konsep-konsep yang dilakukan menjadi lebih mudah dilakukan menggunakan laboratorium virtual karena visualisasi konsep yang disajikan pada materi yang menyerupai bentuk rillnya. Sedangkan pada kelompok kontrol, kegiatan pembelajaran tidak berpusat pada peserta didik, akan tetapi hanya berpusat pada guru yang menjelaskan materi di depan ruangan. Sehingga hal ini berdampak pada tingkat penguasaan konsep peserta didik rendah. Hal ini sejalan dengan penelitian yang dilakukan Tuysuz (2010) yang menyatakan bahwa pada saat pelaksanaan praktikum dengan menggunakan laboratorium virtual lebih efektif, menarik dan lebih bermanfaat serta dapat memungkinkan peserta didik untuk mengulang percobaan dibanding 
dengan kelompok yang menggunakan laboratorium riil karena tidak semua peserta didik aktif dalam proses eksperimen di laboratorium riil. Temuan ini juga didukung oleh Zaini (2009) yang mengemukakan bahwa peserta didik akan mudah mengingat pengetahuan yang diperoleh secara mandiri lebih lama, dibandingkan dengan informasi yang dia peroleh dari mendengarkan orang lain.

Pada penelitian ini juga dilihat perbedaan pencapaian penguasaan konsep peserta didik tiap sub materi kalor antara kelompok ekperimen dan kelompok kontrol. Berdasarkan data penguasaan konsep tiap sub materi antara kedua kelompok, secara keseluruhan nilai ratarata kelompok eksperimen lebih tinggi dibandingkan dengan kelompok kontrol. Perolehan nilai rata-rata penguasaan konsep kedua kelompok pada setiap sub materi disajikan dalam Tabel 2.

Tabel 2. Nilai Rata-Rata Penguasaan Konsep Peserta Didik pada Setiap Sub Materi

\begin{tabular}{lcc}
\hline Sub Materi & $\begin{array}{c}\text { Kelompok } \\
\text { Eksperimen }\end{array}$ & $\begin{array}{c}\text { Kelompok } \\
\text { Kontrol }\end{array}$ \\
\hline Pemuaian & 80,11 & 63,16 \\
Kalor & 77,63 & 61,55 \\
Perubahan Wujud Zat & 41,47 & 39,31 \\
Azas Black & 73,45 & 56,29 \\
Perpindahan Kalor & 38,33 & 32,53 \\
\hline
\end{tabular}

Berdasarkan perolehan nilai rata-rata penguasaan konsep setiap sub materi pada Tabel 2, diketahui bahwa nilai rata-rata tertinggi kelompok eksperimen sebesar 80,11 diperoleh pada sub materi pemuaian, sedangkan nilai rata-rata terendah diperoleh pada sub materi perpindahan kalor yaitu sebesar 38,33. Sedangkan pada kelompok kontrol nilai rata-rata tertinggi sebesar 63,16 diperoleh pada sub materi pemuaian, sedangkan nilai rata-rata terendah diperoleh pada sub materi perpindahan kalor sebesar 32,53. Perolehan nilai rata-rata tertinggi kedua kelompok terjadi pada sub materi pemuaian dan yang terendah pada sub materi perpindahan kalor. Hal ini disebabkan karena instrumen tes pada sub materi pemuaian lebih didominasi oleh aspek kognitif tingkat rendah yang terdiri dari $\mathrm{C}_{1}$ sampai $\mathrm{C}_{3}$, dimana soal-soal tersebut termasuk dalam kategori mudah. Sedangkan pada sub materi perpindahan kalor lebih didominasi oleh aspek kognitif tingkat tinggi yang terdiri dari $\mathrm{C}_{4}$ dan $\mathrm{C}_{5}$, dimana soal-soal tersebut termasuk dalam kategori sulit. Penelitian ini sejalan dengan hasil penelitian Husein et al. (2015) yang menyatakan bahwa pada sub materi pemuaian peserta didik memperoleh nilai ratarata tertinggi dibanding pada sub-sub materi yang lain baik pada kelompok eksperimen maupun kelompok kontrol. Hasil penelitian ini tidak sejalan dengan Nurqomariah et al. (2015) yang menyatakan bahwa peserta didik memperoleh nilai rata-rata tertinggi pada sub materi perpindahan kalor dibandingkan dengan sub-sub materi lainnya. Perbandingan pencapaian penguasaan konsep pada setiap sub materi antara kelompok eksperimen dan kelompok kontrol ditampilkan pada Gambar 2.

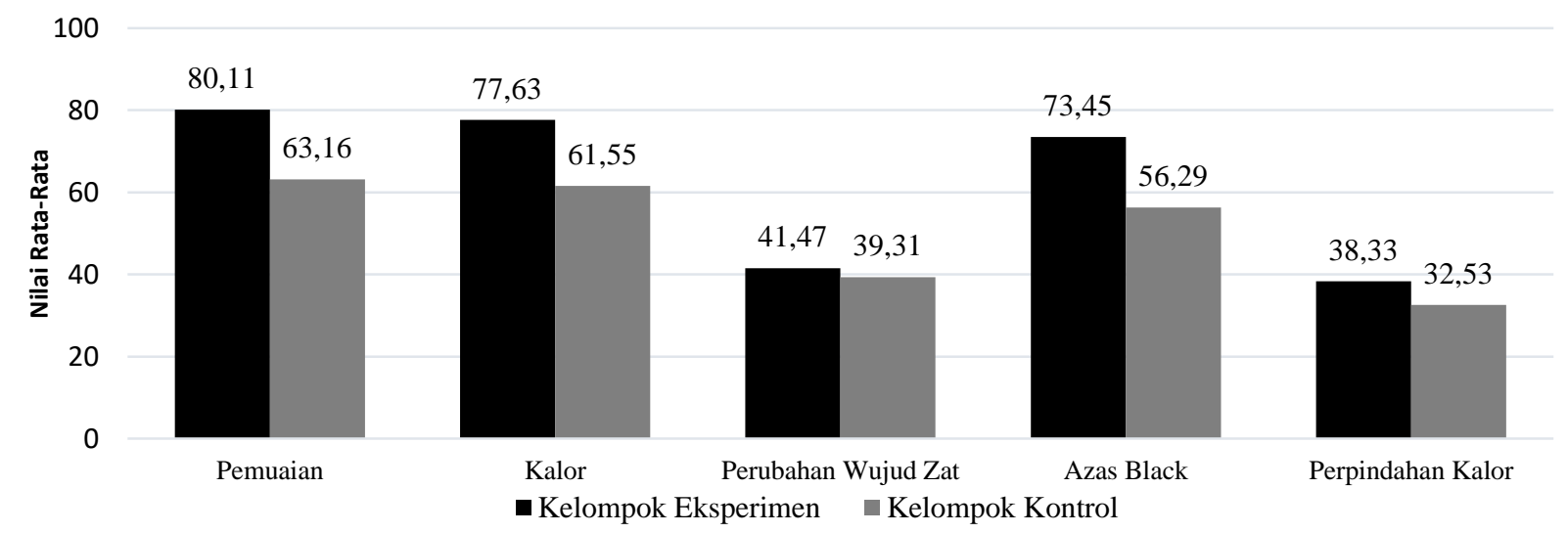

Gambar 2. Perbandingan Nilai Rata-Rata Penguasaan Konsep Peserta Didik pada Setiap Sub Materi 
Tingginya pencapaian penguasaan konsep kelompok eksperimen pada setiap sub materi disebabkan karena pelaksanaan pembelajaran menggunakan laboratorium virtual yang menyajikan informasi-informasi melalui media teks, gambar, video, animasi dan simulasi yang mendukung setiap sub materi serta didukung dengan kegiatan-kegiatan ilmiah yang disajikan dalam lembar kerja untuk melatih peserta didik dalam mengkonstruk pengetahuan akan konsep-konsep kalor secara mandiri.

Meskipun secara keseluruhan pencapaian penguasaan konsep kelompok eksperimen pada setiap sub materi lebih tinggi dibanding kelompok kontrol, namun berdasarkan hasil analisis pada setiap sub materi diperoleh hal yang menarik bahwa penguasaan konsep kedua kelompok tidak berbeda secara signifikan pada sub materi perubahan wujud zat dan perpindahan kalor. Dimana kelompok eksperimen memperoleh nilai rata-rata sebesar 41,47 pada sub materi perubahan wujud zat dan 38,33 pada sub materi perpindahan kalor, sedangkan kelompok kontrol memperoleh nilai rata-rata sebesar 39,31 pada sub materi perubahan wujud zat dan 32,53 pada sub materi perpindahan kalor. Sehingga hal ini menunjukkan bahwa penggunaan laboratorium virtual dalam pembelajaran inkuiri terbimbing tidak berpengaruh secara signifikan terhadap penguasaan konsep peserta didik pada sub materi perubahan wujud zat dan perpindahan kalor. Hasil penelitian ini tidak sejalan dengan Imran et al. (2015) yang menyatakan bahwa multimedia pembelajaran interaktif kalor berpengaruh terhadap hasil belajar kognitif perserta didik pada sub materi perubahan wujud zat.

Perbedaan yang tidak signifikan antara kelompok eksperimen dengan kelompok kontrol pada sub materi perubahan wujud zat disebabkan karena pada soal tentang sub perubahan wujud zat lebih mengharuskan peserta didik untuk mampu memahami konsep melalui tahap-tahap yang disajikan pada grafik perubahan wujud zat dan peserta didik dituntut untuk mampu membuat grafik perubahan wujud zat berdasarkan kegiatan praktikum yang telah dilakukan. Dimana peserta didik pada sub ini masih belum terlalu memahami konsep perubahan wujud zat berdasarkan fase-fasenya, baik di kelompok kontrol maupun di kelompok eksperimen. Selain itu, tidak berpengaruhnya penggunaan laboratorium virtual dalam pembelajaran inkuiri terbimbing pada sub ini dikarenakan soal-soal lebih didominasi oleh soal berbentuk hitungan, yang dimana peserta didik pada kelompok eksperimen tidak terbiasa dengan soal-soal berbentuk hitungan dibanding kelompok kontrol yang lebih menekankan pada drill latihan soal yang diporsir dalam jumlah yang cukup banyak.

Selain pada sub materi perubahan wujud zat, pada sub materi perpindahan kalor juga tidak terdapat perbedaan yang signifikan antara kelompok eksperimen dengan kelompok kontrol. Sehingga penggunaan laboratorium virtual dalam pembelajaran inkuiri terbimbing tidak berpengaruh secara signifikan pada sub materi perpindahan kalor. Hal ini disebabkan karena soal yang digunakan pada sub materi ini lebih menekankan pada contoh kongkrit dari perpindahan kalor dan kemampuan peserta didik dalam menghubungkan informasiinformasi tentang jenis-jenis perpindahan kalor yang telah diterima melalui pembelajaran menggunakan laboratorium virtual dengan contoh kongkrit pada pengaplikasian dalam kehidupan sehari-hari yang masih sangat kurang. Selain itu, pada pelaksanaan pembelajaran dengan menggunakan laboratorium virtual dalam pembelajaran inkuiri terbimbing yang didukung dengan lembar kerja peserta didik masih kurang dalam kemampuan menarik kesimpulan akan 
variabel-variabel yang mempengaruhi terjadinya perpindahan kalor yang berimplikasi pada kurangnya penguasaan konsep peserta didik pada sub materi ini.

Beberapa penjelasan diatas secara umum mengungkapkan bahwa dengan laboratorium virtual yang dikombinasikan dengan model pembelajaran yang tepat ternyata dapat meningkatkan penguasaan konsep peserta didik.

\section{PENUTUP}

Berdasarkan hasil dan pembahasan yang telah dipaparkan dapat disimpulkan bahwa penggunaan laboratorium virtual dalam pembelajaran inkuri terbimbing berpengaruh terhadap penguasaan konsep kalor peserta didik SMAN 4 Mataram Tahun Pelajaran 2017/2018. Pada pelaksanaan pembelajaran menggunakan laboratorium virtual, peserta didik dibagi menjadi beberapa kelompok karena harus disesuaikan dengan jumlah komputer yang dapat digunakan. Oleh karena itu, peneliti menyarankan bagi peneliti selanjutnya untuk mempersiapkan jumlah komputer yang disesuaikan dengan jumlah peserta didik sehingga penggunaan laboratorium virtual dalam proses pembelajaran dapat dilaksanakan secara optimal dan berjalan sesuai dengan tujuan pembelajaran yang diinginkan.

\section{REFERENSI}

Bortnik, B., Stozhko, N., Pervukhina, I., Tchernysheva, A., \& Belysheva, G. 2017. Effect of Virtual Analytical Chemistry Laboratory on Enhancing Student Research Skills and Practices. Research in Learning Technology. 25, 1-20.

Creswell, J. W. 2012. Research Design Pendekatan Kualitatif, Kuantitatif, dan Mixed. Yogyakarta: Pustaka Pelajar.

Gunawan, G., \& Liliasari, L. 2012. Model Virtual Laboratory Fisika Modern untuk Meningkatkan Disposisi Berpikir Kritis
Calon Guru. Jurnal Cakrawala Pendidikan. 5(2), 185-199.

Hayati, S. N., Hikmawati, H., \& Wahyudi, W. 2017. Pengaruh Model Pembelajaran Inkuiri dengan Menggunakan Media Simulasi Terhadap Hasil Belajar Fisika Siswa Kelompok X MIA SMAN 1 Lingsar Lombok Barat Tahun Pelajaran 2016/2017. Jurnal Pendidikan Fisika dan Teknologi. 3(1), 48-54.

Hermansyah, H., Gunawan, G., \& Herayanti, L. 2017. Pengaruh Penggunaan Laboratorium Virtual Terhadap Penguasaan Konsep dan Kemampuan Berpikir Kreatif Siswa pada Materi Getaran dan Gelombang. Jurnal Pendidikan Fisika dan Teknologi. 1(2), 97-102.

Husein, S., Herayanti, L., \& Gunawan, G. 2015. Pengaruh Penggunaan Multimedia Interaktif Terhadap Penguasaan Konsep dan Keterampilan Berpikir Kritis Siswa pada Materi Suhu dan Kalor. Jurnal Pendidikan Fisika dan Teknologi. 1(3), 221-225.

Imran., Harjono, A., \& Gunawan, G. 2015. Efek Multimedia Pembelajaran pada Kemampuan Siswa Menjawab Soal Analisis Energi pada Perubahan Wujud Air: Sebuah Tinjauan pada Siswa Kelas X Sman 3 Mataram. Jurnal Pendidikan Fisika dan Teknologi. 1(1), 47-51.

Junaidi, J., Gani, A., \& Mursal, M. 2016. Model Virtual Laboratory Berbasis Inkuiri untuk Meningkatkan Keterampilan Generik Sains Siswa MA. Jurnal Pendidikan Sains Indonesia. 4(2), 130-136.

Kusdiastuti, M., Harjono, A., Sahidu, H., \& Gunawan, G. 2016. Pengaruh Model Pembelajaran Inkuiri Berbantuan Laboratorium Virtual Terhadap Penguasaan Konsep Fisika Peserta Didik. Jurnal Pendidikan Fisika dan Teknologi. 2(3), 116-122.

Muthmainnah, M., \& Rokhmat, J. 2017. Pengaruh Penerapan Metode Pembelajaran Fisika Berbasis Eksperimen Virtual Terhadap Motivasi 
Dan Hasil Belajar Fisika Siswa Kelas X MAN 2 Mataram Tahun Ajaran 2014/2015. Jurnal Pendidikan Fisika dan Teknologi. 3(1), 40-47.

Nugroho, S. 2013. Pembelajaran IPA Dengan Metode Inkuiri Terbimbing Menggunakan Laboratorium Riil Dan Virtuil Ditinjau dari Kemampuan Memori Dan Gaya Belajar Siswa. Jurnal Inkuiri. 1(3), 235-244.

Nurqomariah, N., Gunawan, G., \& Sutrio, S. 2015. Pengaruh Model Problem Based Learning dengan Metode Eksperimen Terhadap Hasil Belajar IPA Fisika Siswa Kelas VII SMP Negeri 19 Mataram Tahun Pelajaran 2014/2015. Jurnal Pendidikan Fisika dan Teknologi. 1(3), 173-179.

Pullaila, A. 2007. Model Pembelajaran Inkuiri Terbimbing Untuk Meningkatkan Penguasaan Konsep Dan Keterampilan Berpikir Kreatif Peserta didik SMA Pada Materi Suhu Dan Kalor. Jurnal Penelitian Pendidikan IPA. Prodi IPA SPS UPI Bandung. 1(3).

Sugiana, I. N., Harjono, A., Sahidu, H., \& Gunawan, G. 2016 Pengaruh Model Pembelajaran Generatif Berbantuan Media Laboratorium Virtual Terhadap Penguasaan Konsep Fisika Siswa pada Materi Momentum dan Impuls. Jurnal Pendidikan Fisika dan Teknologi. 2(2), 61-65.

Tuysuz, C. 2010. The Effect of the Virtual Laboratory on Students' Achievement and Attitude in Chemistry. International Online Journal of Educational Sciences. 2(1), 37-53.

Wahyana. 2001. Perencanaan dan pengelolaan Pembelajaran IPA. Jakarta: Universitas Terbuka.

Zaini, H. 2009. Strategi Pembelajaran Aktif Implementasi dan Kendalanya di dalam Kelas. In Seminar Nasional VII Pendidikan Biologi. 6(1), 1-11. 